\title{
VICKZ proteins mediate cell migration via their RNA binding activity
}

\author{
FROMA OBERMAN, KINNERET RAND, ${ }^{1}$ YAEL MAIZELS, ARIEL M. RUBINSTEIN, ${ }^{2}$ and JOEL K. YISRAELI \\ Department of Anatomy and Cell Biology, Hebrew University, Hadassah Medical School, Jerusalem 91120, Israel
}

\begin{abstract}
The highly conserved, RNA binding VICKZ proteins help regulate RNA localization, stability, and translation in many eukaryotes. These proteins are also required for cell migration in embryos and cultured cells. In adults, many tumors overexpress VICKZ homologs, and it has been hypothesized that the proteins can mediate cell motility and invasion. How these proteins facilitate cell movement and, in particular, whether their ability to bind RNA plays a role in their function remain unclear. Using HPLC and mass spectrometry to identify a region of Xenopus Vg1 RBP (xVICKZ3) that binds the vegetal localization element of Vg1 RNA, we generated a deletion construct that functions in a dominant-negative manner. The construct associates with full-length $x$ VICKZ3 and severely reduces binding to target RNAs. This dominant-negative construct phenocopies the effect of down-regulating xVICKZ3 in Xenopus embryos. A corresponding deletion in the human homolog hVICKZ1 similarly functions in a dominant-negative fashion to reduce the ability of full-length hVICKZ protein to bind RNA. Expression of the dominant-negative construct in human carcinoma cells inhibits cell movement by several criteria. We conclude that the ability of VICKZ proteins to mediate cell migration, in vitro and in vivo, requires their RNA binding activity.
\end{abstract}

Keywords: Vg1 RBP; ZBP1; Igf2 mRNA binding proteins; RNA localization; cell motility; Biacore; MALDI-TOF

\section{INTRODUCTION}

VICKZ proteins constitute a small family of highly conserved RNA binding proteins (Yisraeli 2005). In Xenopus laevis, there is a single member of this family, termed Vg1 RBP (Havin et al. 1998) or Vera (Deshler et al. 1998), that was initially identified based on its ability to bind Vg1 RNA with high affinity. Vg1 RBP, or xVICKZ3 (according to the terminology suggested in Yaniv and Yisraeli 2002), is part of a complex of several RNA binding and motor proteins that help localize Vg1 RNA to the vegetal cortex of Xenopus oocytes in a mechanism requiring both intact microtubules and microfilaments (Yisraeli et al. 1990; Elisha et al. 1995; Cote et al. 1999; Zhao et al. 2001; Kroll et al. 2002; Allison et al. 2004; Betley et al. 2004; Lewis et al. 2004; Yoon and

Present addresses: ${ }^{1}$ Laboratory of Molecular Genetics, NICHD, NIH, Bethesda, MD, USA; ${ }^{2}$ Department of Biochemistry, Jerusalem College of Technology, Jerusalem 91120, Israel.

Reprint requests to: Joel K. Yisraeli, Department of Anatomy and Cell Biology, Hebrew University, Hadassah Medical School, POB 12272, Jerusalem 91120, Israel; email: yisraeli@cc.huji.ac.il; fax: +972 2675 7451; or Ariel M. Rubinstein, Department of Biochemistry, Jerusalem College of Technology, Jerusalem 91120, Israel; e-mail: amrubinstein@ gmail.com.

Article published online ahead of print. Article and publication date are at http://www.rnajournal.org/cgi/doi/10.1261/rna.559507.
Mowry 2004; Czaplinski et al. 2005; Czaplinski and Mattaj 2006). In Xenopus embryos, xVICKZ3 plays a role in single cell movements. Antisense morpholino oligonucleotides (AMO) directed against $\mathrm{xVICKZ3} \mathrm{mRNA}$, which reduce expression of the protein by $80 \%$, prevent migration of both neural crest cells and cells that form the roof plate of the neural tube (Yaniv et al. 2003). Indeed, $x$ VICKZ3 is expressed at the leading edge of normal neural crest cells migrating out of explanted neural tubes, and only those cells retaining residual xVICKZ3 expression are capable of movement out of an AMO-treated neural tube explant.

Involvement of VICKZ proteins in cell morphology and/ or movement has been reported in a number of other organisms and cell types as well. In rats, dendritic spine density is modulated by the levels of expression of rVICKZ1 (rat VICKZ1) in hippocampal neurons (Eom et al. 2003). In HeLa cells, hVICKZ1 and hVICKZ3 appear to play a role in regulating cell adhesion and invadopodia formation (Vikesaa et al. 2006). In chicks, the cVICKZ1, termed $\mathrm{ZBP} 1$, promotes translocation of $\beta$-actin mRNA to actinrich protrusions at the leading edge of migrating fibroblasts and neurons (Ross et al. 1997; Farina et al. 2003; Oleynikov and Singer 2003), and localized $\beta$-actin mRNA is important in maintaining persistence of motion in motile cells (Shestakova et al. 2001). Recently, in Xenopus laevis axons, 
asymmetric localization and translation of $\beta$ actin mRNA, mediated by $x$ VICKZ, have been shown to play a role in axonal guidance (Leung et al. 2006; Yao et al. 2006). These observations have all led to the proposal that VICKZ proteins play an essential role in cell movement through their ability to localize requisite RNAs (Condeelis and Singer 2005; Yisraeli 2005).

All of the vertebrate VICKZ homologs contain two RNA recognition motifs (RRMs) at the $\mathrm{N}$ terminus of the protein, and four hnRNP $\mathrm{K}$ homology $(\mathrm{KH})$ domains at the $\mathrm{C}$ terminus. The Xenopus and human homologs are between $70 \%$ and $84 \%$ identical across the almost 600 amino acid length of the protein, with the highest regions of conservation in the RNA binding motifs (Zhang et al. 1999; Yaniv and Yisraeli 2002). KH domains 3 and 4 have been implicated in mediating not only RNA binding (Git and Standart 2002; Farina et al. 2003) but also selfassociation of the protein (Git and Standart 2002; Nielsen et al. 2004). In addition, VICKZ proteins appear to associate with a number of other proteins in ribonucleoprotein particles (Moraes et al. 2003; Kress et al. 2004; Yoon and Mowry 2004; Patel et al. 2005). These findings raise the question of whether VICKZ proteins play a role in cell movement via their RNA binding activity, protein-protein interactions, or a combination of both.

Here we report the construction of a deletion mutant of xVICKZ3 that, through its association with full-length $x V I C K Z 3$, acts in a dominant-negative fashion to inhibit RNA binding. Both in Xenopus embryos and in human bladder carcinoma cells, dominant-negative inhibition severely impairs cell migration. These results demonstrate the requirement of VICKZ RNA binding in mediating cell movement.

\section{RESULTS}

\section{Defining a functional RNA binding site in $x$ VICKZ3}

To determine which of the six putative RNA binding domains (two RRMs and four KH domains) in xVICKZ3 bind the VLE sequence in Vg1 RNA, we used mass spectrometry to identify peptides cross-linked to the RNA. Purified, recombinant xVICKZ3 binds VLE RNA with high affinity and specificity in vitro, as shown by both gel shift and UV-cross-linking assays (Fig. 1A). xVICKZ3 was UV-cross-linked to VLE RNA, digested with trypsin, and the resulting peptides separated by high performance liquid chromatography (HPLC). When compared with the profile of peptides obtained from mock UV-crosslinked xVICKZ3, one major novel peak was observed in the VLE UV-cross-linked sample that was absent from the mock UV-cross-linked sample (Fig. 1B). This peak was analyzed by MALDI-TOF and found to contain a single peptide (Fig. 1B). The sequence of the cross-linked peptide was determined by Edmond degradation and found to correspond to a 15 amino acid sequence in the last $\mathrm{KH}$ domain of the protein (Fig. 1C).

In order to confirm that this region in the fourth $\mathrm{KH}$ domain (KH4) of xVICKZ3 binds VLE RNA, we deleted part of $\mathrm{KH} 4$ and assayed its effect on binding. $\mathrm{KH}$ domains generally consist of a $\beta \alpha \alpha \beta \beta \alpha$ structure (Musco et al. 1996). We noted that the last $\alpha$-helix in KH4 is predicted to form a coiled-coil structure ( $98 \%$ probability using the PEPCOIL program based on Lupas et al. 1991). A number of $\mathrm{KH}$ domains in general, and coiled-coil structures in particular, have been shown to mediate protein-protein interactions (Gibson et al. 1993; Chen et al. 1997). In addition, Git and Standart (2002) have suggested that xVICKZ3 self-association requires sequences in the KH3KH4 region. We therefore deleted only the first 52 amino acids of KH4, which included the cross-linked peptide identified by mass spectrometry but was predicted to leave the last $\alpha$-helix intact. This construct, $\mathrm{xVICKZ} 3 \Delta 4$, is, in fact, almost completely inactive in RNA binding in a UVcross-linking assay with a radioactive VLE probe (Fig. 1D). The partial KH4 deletion disrupts UV-cross-linking to additional xVICKZ3 targets as well. As seen in Figure 1D, His-tag-purified $\mathrm{xVICKZ} 3 \Delta 4$ does not bind to TGF $\beta-5$ RNA, previously identified as a vegetally localized xVICKZ3 target in Xenopus oocytes (Schwartz et al. 1992). These results suggest that the deletion affects the ability of $\mathrm{xVICKZ3}$ to bind multiple target RNAs.

Strikingly, the effect of the deletion is not restricted to the deleted molecule itself. When xVICKZ3 $\Delta 4$ is mixed with full-length, His-tag-purified xVICKZ3, the ability of the full-length $x$ VICKZ 3 to bind either a VLE or TGF $\beta-5$ probe is abrogated almost completely (Fig. 2A,B). This trans-dominant inhibition is also observed with endogenous xVICKZ3 when oocyte extracts are mixed with xVICKZ3 $\Delta 4$ (Fig. 2C). These results cannot be explained by simply positing that the probe is sequestered by $\mathrm{xVICKZ} 3 \Delta 4$ because, even in the presence of several-fold excess probe, no cross-linking to the full-length xVICKZ3 (or to xVICKZ3 $\Delta 4$ ) is observed (data not shown). Knowing the approximate concentration of endogenous $x$ VICKZ3 in the extracts, and the amount of xVICKZ3 $\Delta 4$ necessary to titrate out the binding activity, we estimate that maximal inhibition is achieved at around equimolar amounts of $x V I C K Z 3$ and $x V I C K Z 3 \Delta 4$. Thus, $x V I C K Z 3 \Delta 4$ appears to act as a dominant-negative inhibitor of full-length $x V I C K Z 3$ RNA binding in vitro.

One possible explanation of how $\mathrm{xVICKZ} 3 \Delta 4$ functions as a dominant-negative inhibitor is that it associates with xVICKZ3. Such a heteromere could disrupt the normal, sequential dimerization that has been observed for VICKZRNA interactions and is thought to stabilize the RNP complex (Nielsen et al. 2004) (see Discussion). To test whether heteromeres are likely to form, and to determine the dissociation constant of the protein-protein interaction, 

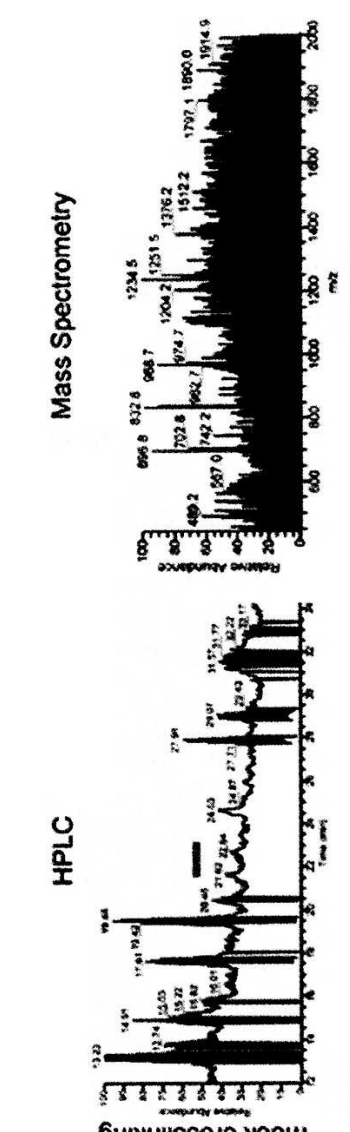

$\infty$
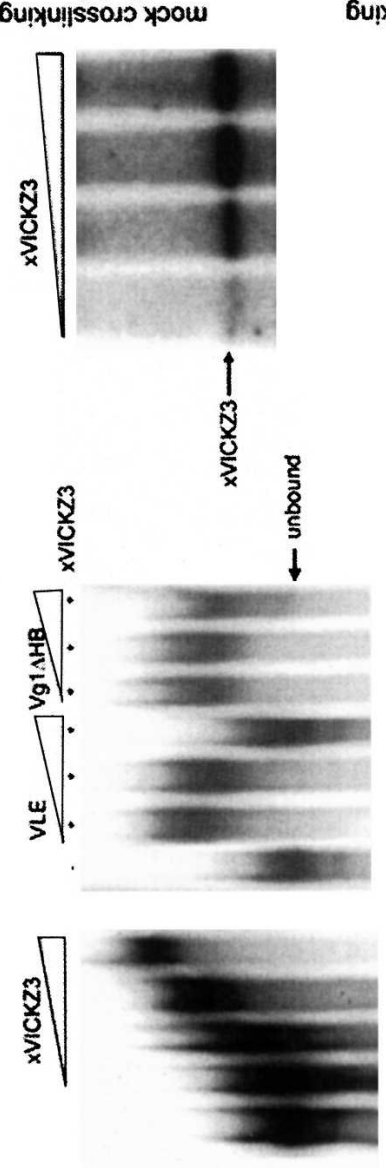
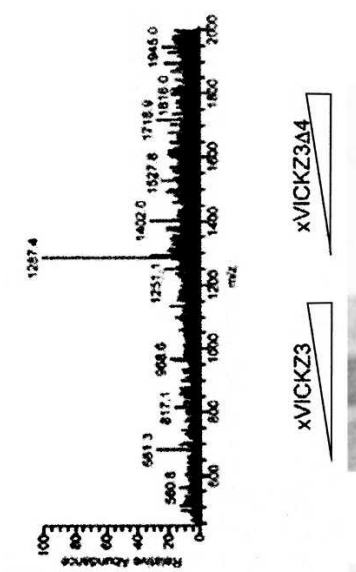

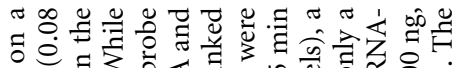



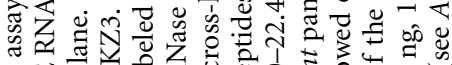

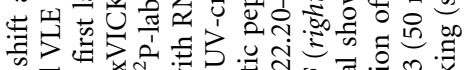

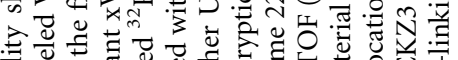

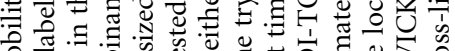
击

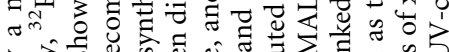

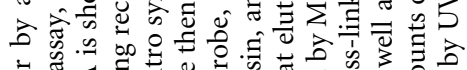



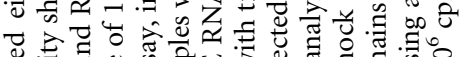

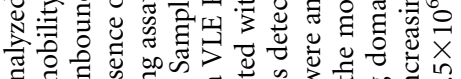
तै

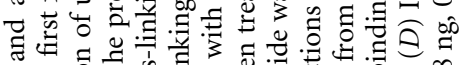
ऊ.t.

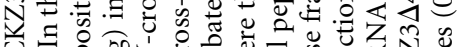

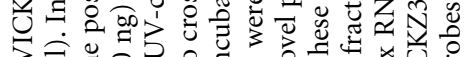





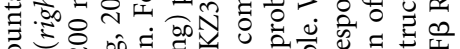

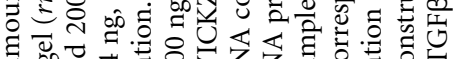



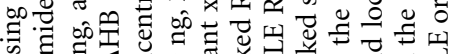

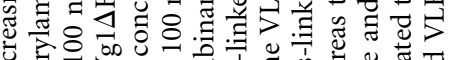

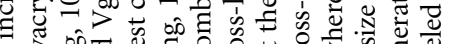

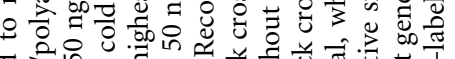

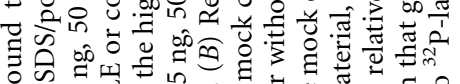

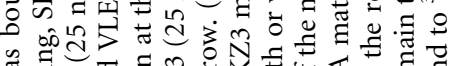

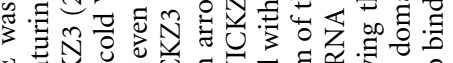
떠 준 $>$ 过论

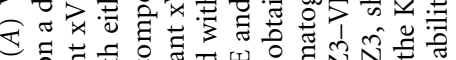

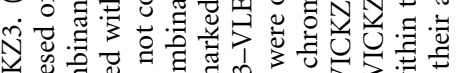

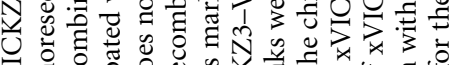


$\forall$ के

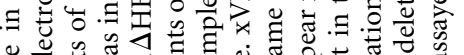

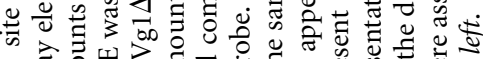

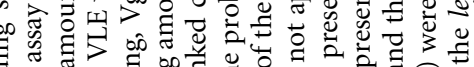

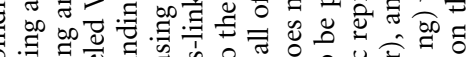

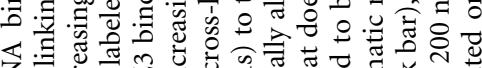

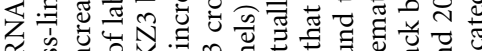



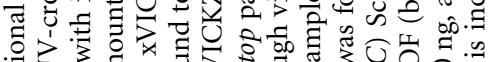

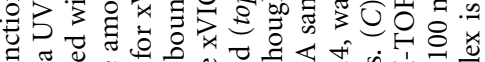

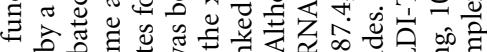
获它式

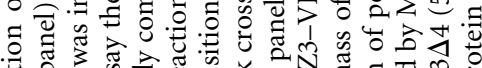

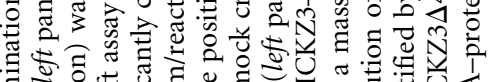

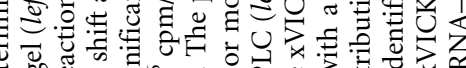

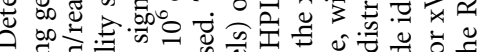

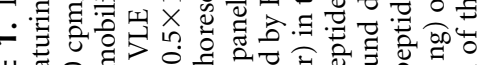
㟧

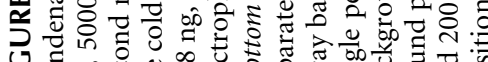

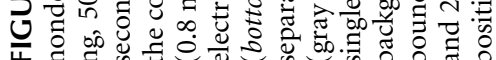




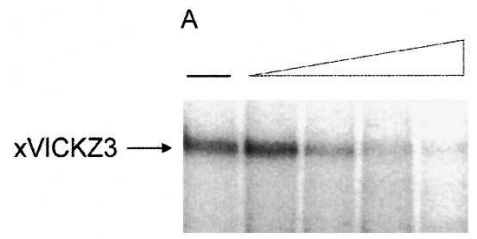

probe:
B

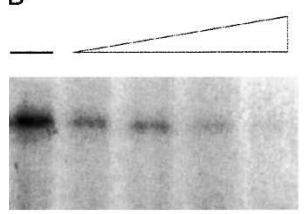

TGF $\beta$
C

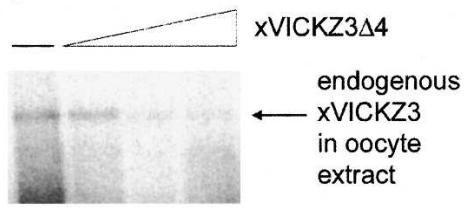

VLE

FIGURE 2. Interference of $x$ ICKZ3 binding by recombinant $x$ VICKZ3 $\Delta 4 .{ }^{32} \mathrm{P}$-labeled VLE RNA $\left(0.5 \mathrm{ng}, 0.5 \times 10^{6} \mathrm{cpm}\right)$ was incubated with 50 ng of full-length recombinant XVICKZ3 in the absence (-) or presence of increasing amounts of xVICKZ3 4 (50 ng, $100 \mathrm{ng}, 250 \mathrm{ng}$, and $500 \mathrm{ng})$ prior to UV-cross-linking $(A)$. As increasing amounts of $x V I C K Z 3 \Delta 4$ were included in the reaction, the binding of the full-length protein to the RNA probe was reduced. The same results were obtained when a TGF $\beta$ probe $\left(0.5 \mathrm{ng}, 0.5 \times 10^{6} \mathrm{cpm}\right)$ was incubated with purified $\mathrm{xVICKZ3}$ under identical experimental conditions $(B)$, and when VLE RNA was UV-cross-linked to $5 \mu \mathrm{g}$ of oocyte extract in the absence (-) or presence of increasing amounts of $x$ VICKZ3 $44(10 \mathrm{ng}, 40 \mathrm{ng}$, and $100 \mathrm{ng})$. The position of the (recombinant) xVICKZ3 UV-cross-linked complex is marked by an arrow on the left $(A, B)$, and the endogenous xVICKZ3 UV-cross-linked band is indicated on the right $(C)$.

xVICKZ3 was immobilized as the ligand on a Biacore sensor chip, and an equilibrium binding analysis, with increasing concentrations of $\mathrm{xVICKZ3}$ or $\mathrm{xVICKZ} 3 \Delta 4$ as an analyte, was performed (Fig. 3A,B). The dissociation constant of $x$ VICKZ3 with itself is $\mathrm{K}_{\mathrm{D}}=5.18 \times 10^{-9} \mathrm{M}$. (BSA, with approximately the same molecular weight as $\mathrm{xVICKZ3}$, shows no appreciable association at all with xVICKZ3 when used as an analyte; data not shown.) $\mathrm{xVICKZ} 3 \Delta 4$ shows a similar affinity for $\mathrm{xVICKZ3}\left(\mathrm{K}_{\mathrm{D}}=\right.$ $\left.5.05 \times 10^{-9} \mathrm{M}\right)$. Together, these results strongly support the hypothesis that $\mathrm{xVICKZ} 3 \Delta 4$, through its association with the full-length protein, impairs the ability of $\mathrm{xVICKZ3}$ to bind RNA.

\section{xVICKZ3 RNA binding activity is required for its normal function in embryos}

We have shown that $x$ VICKZ3 is required for certain cell migrations in embryos (Yaniv et al. 2003). Thus, AMO that are directed against $\mathrm{xVICKZ3}$ RNA and reduce the level of the protein by $\sim 80 \%$, lead to an inhibition of neural crest and roof plate cell movement. These treated embryos have a distinct phenotype, with little or no lens formation, a disorganized pigmented retina, a reduction in lateral pigment and dorsal fin, and head and trunk abnormalities. It has been suggested that, in analogy to ZBP-1's ability of binding $\beta$-actin RNA in migrating chick embryo fibroblasts, xVICKZ3 may be required for moving requisite RNAs to the leading edge of motile cells (Yaniv and Yisraeli 2002; Yaniv et al. 2003; Wang et al. 2004; Yisraeli 2005).

To determine whether xVICKZ3's ability to bind RNA is involved in its role in cell migration, RNA encoding an $\mathrm{xVICKZ3} \Delta 4-\mathrm{GFP}$ fusion protein was injected into both blastomeres of two-cell stage embryos, and their development was compared to wild-type and xVICKZ3 AMOinjected embryos. As shown in Figure 4A, embryos injected with $\mathrm{xVICKZ} 3 \Delta 4$ RNA phenocopy those injected with the AMO, showing particularly impaired lateral pigment
A.

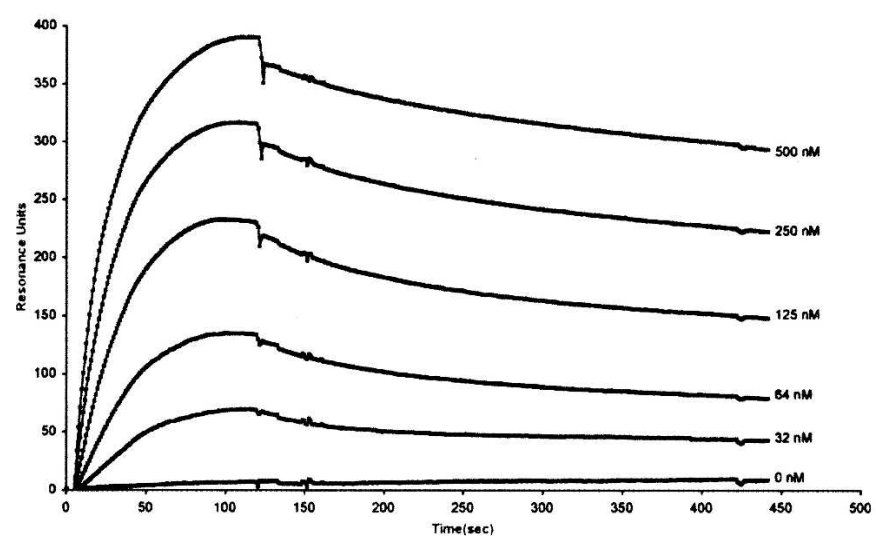

B.

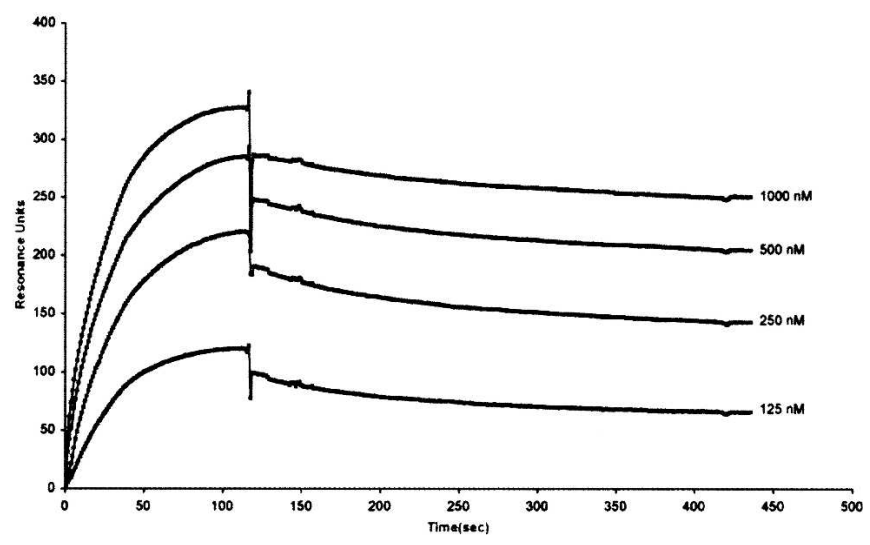

FIGURE 3. Kinetics of $x$ VICKZ3 and $x$ ICKZ3 44 association. To determine dissociation constants $\left(\mathrm{K}_{\mathrm{D}}\right)$ for $\mathrm{xVICKZ3-xVICKZ3} \mathrm{and} \mathrm{xVICKZ3-}$

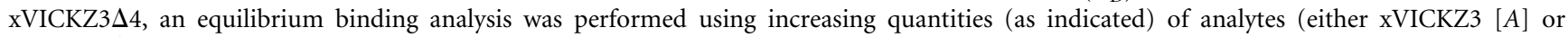
$\mathrm{xVICKZ3} \Delta 4[B]$ ) that were passed over a chip containing immobilized xVICKZ3. The data were subjected to global fitting based on a one-to-one binding model, and all the fittings were judged satisfactory based on the small $\chi^{2}$ values obtained ( $<5 \%$ of the maximum Relative Units). 
A

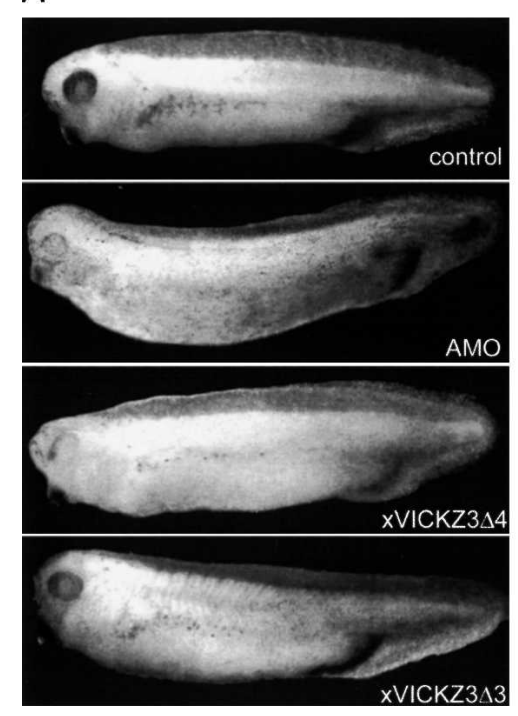

B

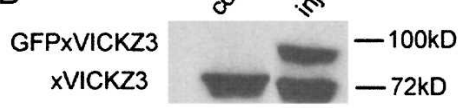

C

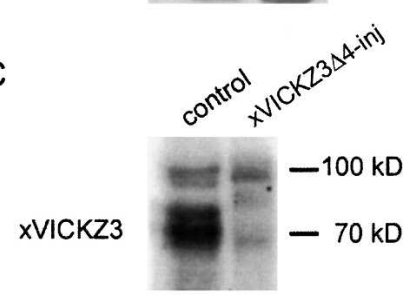

$\mathrm{D}$

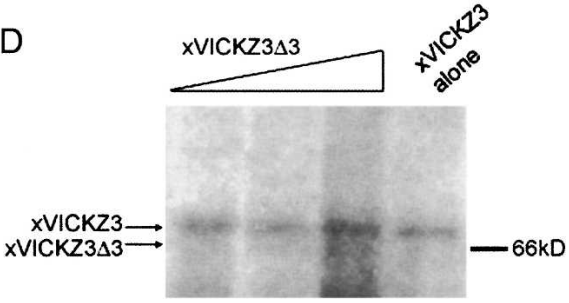

FIGURE 4. Injection of GFP-xVICKZ3 34 RNA phenocopies the specific effect of antisense xVICKZ3 morpholino oligonucleotides on Xenopus development. (A) Two-cell stage embryos were injected in both blastomeres with either $0.8 \mathrm{pmol} /$ blastomere AMO or $2 \mathrm{ng} / \mathrm{blastomere}$ GFP-xVICKZ3 $\Delta 4$ RNA and allowed to develop to the tailbud stage. Embryos injected with GFP-xVICKZ3 $\Delta 4$ RNA phenocopied embryos injected with the AMO. Note the abnormal head development, reduced dorsal fin, lack of lens development, and severe reduction in normal pigmentation in GFP-xVICKZ3 $\Delta 4$ RNA-injected embryos. Embryos injected with 2 ng/blastomere xVICKZ3 $\Delta 3$ RNA developed normally. (B) Proteins were extracted from tailbud stage, uninjected (control) embryos, or from embryos injected with GFP-xVICKZ3 $\Delta 4$ RNA. One embryo equivalent was loaded in each lane, and xVICKZ3 and GFP-xVICKZ3 $\Delta 4$ expression were compared following electrophoresis by Western blot analysis using an antiVICKZ antibody. $(C)$ Three embryo equivalents of the same extracts that were used for the Western blot were UV-cross-linked with ${ }^{32} \mathrm{P}$-labeled VLE probe. Injected GFP-xVICKZ3 $\Delta 4$ significantly inhibited the binding of the endogenous xVICKZ3 to the RNA. $(D){ }^{32} \mathrm{P}$-labeled VLE RNA $\left(0.5 \mathrm{ng}, 0.5 \times 10^{6} \mathrm{cpm}\right)$ was incubated with $50 \mathrm{ng}$ of full-length recombinant $\mathrm{xVICKZ3}$ in the absence or presence of increasing amounts of xVICKZ3 33 (50 ng, $250 \mathrm{ng}$, and $500 \mathrm{ng}$ ) prior to UV-cross-linking. Even at high concentrations of xVICKZ3 $\Delta 3$, no UV-crosslinking of the deleted construct is observed, and there is also no reduction in the binding of the full-length protein to the RNA probe. (The sizes of the full-length and deleted construct are indicated by arrows on the left of the gel.)

migration, lens development, and head and trunk abnormalities. Increasing the amount of injected xVICKZ3 $\Delta 4$ RNA leads to an increase in the percent of mutant embryos, and a similar high percentage of mutants can be obtained with either xVICKZ3 44 RNA or with xVICKZ3 AMO injections (Table 1). In embryos injected with $2 \mathrm{ng} /$ blastomere of xVICKZ3 $\Delta 4-$ GFP RNA, almost equimolar amounts of
$\mathrm{xVICKZ3}$ and the $\mathrm{xVICKZ3} \Delta-\mathrm{GFP}$ fusion protein are observed in whole embryo extracts (Fig. 4B). Despite essentially identical levels of xVICKZ3 protein in uninjected or injected embryos, expression of the $\mathrm{xVICKZ} 3 \Delta 4-\mathrm{GFP}$ fusion protein severely inhibits the ability of the endogenous xVICKZ3 to bind Vg1 VLE RNA (Fig. 4C).

Although the phenotype of the $\mathrm{xVICKZ3} \Delta 4-\mathrm{GFP}$-injected embryos is essentially identical to that of the AMOinjected embryos, the deleted protein could theoretically affect embryonic development via interactions with molecules other than full-length xVICKZ3. To eliminate this possibility, we generated another deletion mutant of xVICKZ3 and tested its effects on embryonic development following injection. xVICKZ3 33 was made by deleting the region of $\mathrm{KH} 3$ in $\mathrm{xVICKZ3}$ corresponding to the deleted region of KH4 in xVICKZ3 44 (see Materials and Methods). This deletion, while inhibiting the ability of the protein itself to bind VLE RNA, does not affect the VLE RNA binding ability of full-length xVICKZ3 when incubated together with it (Fig. 4D). Thus, we predicted that $\mathrm{xVICKZ} 3 \Delta 3$, although very closely related to $x$ VICKZ3 $\Delta 4$, could not act in a dominant-negative manner, and would therefore have little effect on embryonic development. In fact, when injected into both blastomeres of two-cell embryos, $\mathrm{xVICKZ} 3 \Delta 3$ had very little effect $(8 / 11$, or $73 \%$, showed a normal phenotype; Fig. $4 \mathrm{~A})$, at a concentration where $\mathrm{xVICKZ3} \Delta 4$ showed high penetrance $(14 / 18$, or $78 \%$, of the embryos in this set of experiments were mutant). These results demonstrate not only the specificity of the $\mathrm{xVICKZ} 3 \Delta 4$-mediated dominant-negative inhibition, but also the requirement of RNA binding for xVICKZ3's function in embryonic cell migrations.

TABLE 1. Effect of GFP-xVICKZ3 34 on Xenopus embryos

\begin{tabular}{|c|c|c|c|c|}
\hline Injection (per blastomere) & $\begin{array}{l}\text { Total number } \\
\text { of embryos }\end{array}$ & $\begin{array}{l}\% \text { Normal embryos } \\
\text { (number of embryos) }\end{array}$ & $\begin{array}{l}\% \text { Mutant embryos } \\
\text { (number of embryos) }\end{array}$ & Number of trials \\
\hline Control & 361 & $93 \%(335)$ & $7 \%(26)$ & 8 \\
\hline $\mathrm{AMO}(0.8-1.2 \mathrm{pmol})$ & 77 & $23 \%(18)$ & $77 \%(59)$ & 3 \\
\hline 0.8 ng GFP-xVICKZ3 $\Delta 4$ mRNA & 26 & $73 \%(19)$ & $27 \%(7)$ & 2 \\
\hline 1.2 ng GFP-xVICKZ3 $\Delta 4$ mRNA & 56 & $43 \%(24)$ & $57 \%(32)$ & 3 \\
\hline 2 ng GFP-xVICKZ3 34 mRNA & 134 & $19 \%(26)$ & $81 \%(108)$ & 5 \\
\hline
\end{tabular}




\section{Human VICKZ proteins mediate cell migration via their RNA binding activity in bladder carcinoma cells}

There are three VICKZ isoforms encoded in the human genome, on three separate chromosomes (Yaniv and Yisraeli 2001). The high degree of homology among the VICKZ proteins across both isoforms and species raised the possibility that deletion of the KH4 domain from hVICKZ proteins might also inhibit cell migration in somatic motile cells that express one or more of the VICKZ isoforms. We generated the corresponding deletion in the human isoforms hVICKZ1 and hVICKZ2 and tested their effects on the endogenous hVICKZ proteins in HEK293 cells. As seen in Figure 5A, when a radioactive IGF2-leader 3 RNA probe is UV-cross-linked to a protein extract of HEK293 cells transfected with GFP alone, three prominent proteins are labeled: the VICKZ proteins, at $63 \mathrm{kDa}$ (293 cells express all three hVICKZ proteins; data not shown), and two other unidentified bands at $\sim 50$ and $120 \mathrm{kDa}$. When full-length hVICKZ1 or hVICKZ2, fused to GFP, is transfected into these cells, a fourth, additional labeled band, representing the chimeric protein, is observed; the other bands remain essentially unchanged. Transfection of either hVICKZ1 $\Delta 4$ or hVICKZ2 $\Delta 4$, however, specifically inhibits UV-crosslinking by the endogenous hVICKZ isoforms, while the other bands appear to bind the leader 3 RNA probe normally. As seen with xVICKZ3 $\Delta 4$, neither of the transfected human deletion constructs (distinguishable from the endogenous hVICKZ proteins by virtue of their being fused to GFP) bind its target RNA probe. Deletion of KH4 did not reduce the ability of the deletion construct to associate with the full-length protein, as demonstrated by the ability of transfected GFP-hVICKZ1 $\Delta 4$ to pull down endogenous hVICKZ proteins when immunoprecipitated with anti-GFP antibody (Fig. 5B). These data correlate nicely with in vitro data obtained from a Biacore equilibrium binding analysis (data not shown), showing that hVICKZ1 has a 3.4-fold higher affinity for hVICKZ1 $\Delta 4$ than for itself $\left(\mathrm{K}_{\mathrm{D}}\right.$ of hVICKZ1-hVICKZ1 $=1.98 \times 10^{-7} \mathrm{M}$; $\mathrm{K}_{\mathrm{D}}$ of hVICKZ1-hVICKZ1 $\left.\Delta 4=5.81 \times 10^{-8} \mathrm{M}\right)$. Thus, deletion of the KH4 region in either hVICKZ1 or hVICKZ2 creates a construct that functions in a dominant-negative fashion on RNA binding, just as the corresponding deletion in XVICKZ3 does.

Using the hVICKZ1 $\Delta 4$ construct, we examined the effect of inhibiting RNA binding activity of VICKZ proteins on cell movement in bladder carcinoma cells induced to migrate. Sparsely seeded TSU-Pr1 cells were transiently transfected with plasmids encoding GFP, GFP-hVICKZ1, or GFP-hVICKZ1 14 under conditions where only a fraction of the cells on the plate incorporate the plasmid (thus providing an internal control for the transfected cells). Following $3 \mathrm{~h}$ of serum starvation, migration was induced by the addition of EGF (data not shown); these conditions were found to induce movement in over $90 \%$ of the cells (see Materials and Methods; A.M. Rubinstein and J.K. Yisraeli, in prep.). Three separate parameters of cell movement were used to analyze movies of the induced,

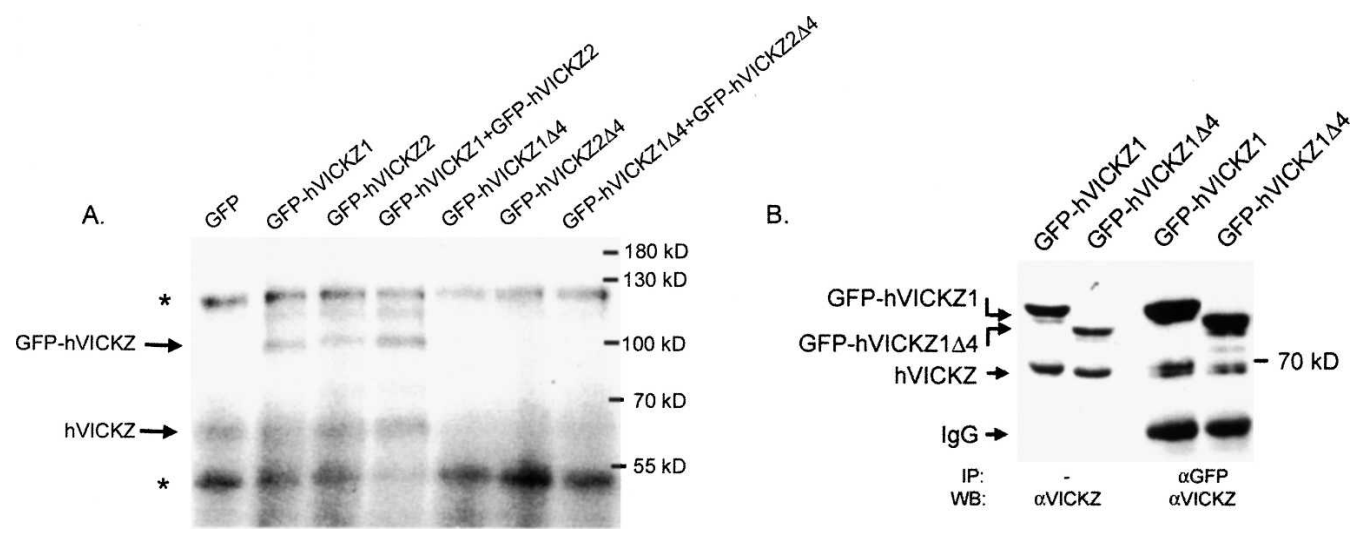

FIGURE 5. hVICKZ 44 functions as a dominant-negative construct in 293 cells. (A) Cross-linking reactions were performed on cell extracts (20 $\mu \mathrm{g}$ ) which had been transfected with various GFP-conjugated constructs (as shown on top of each lane), using a ${ }^{32} \mathrm{P}$-labeled IGF2-leader 3 probe $\left(0.5 \mathrm{ng}, 0.5 \times 10^{6} \mathrm{cpm}\right)$. The full-length constructs, GFP-hVICKZ1 and GFP-hVICKZ2, bind the radioactive RNA in the cross-linking reaction, both when transfected individually or together into 293 cells, and the RNA binding of endogenous hVICKZ in these cell extracts is unaffected (arrows on the left indicate the positions of the endogenous and exogenous cross-linked proteins). Transfection of the GFP-hVICKZ 4 proteins, however, inhibits binding of endogenous hVICKZ to the RNA, and the exogenous proteins also do not cross-link the radioactive probe. The binding of two unidentified proteins of $\sim 125 \mathrm{kDa}$ and $50 \mathrm{kDa}$ (marked with ${ }^{\star}$ ) is similar in all lanes and not only serve as loading controls but also to demonstrate that the inhibition of the dominant negative construct is specific for VICKZ proteins. Molecular weight markers are shown to the right of the gel. (B) Western blot analysis with $\alpha$-VICKZ antibody was performed on equivalent amounts of cell extracts from 293 cells transfected with either full-length GFP-hVICKZ or GFP-hVICKZ $\Delta 4$, and immunoprecipitated with an $\alpha$-GFP antibody. The relative levels of endogenous and exogenous protein in both transfections appear to be identical, as demonstrated in the first two lanes (containing the total cell extract without immunoprecipitation). The arrows at the left of the gel show the positions of the immunoprecipitated GFP-fusion constructs as well as the endogeous hVICKZ proteins. The position of the IgG heavy chains of the $\alpha$-GFP antibody, which are also detected by the anti-rabbit secondary antibody, is indicated as well. 
transfected cells. First, the fraction of transfected, fluorescent cells demonstrating any movement (measured as movement of the nucleus) in a given field was normalized to the fraction of nontransfected, nonfluorescent cells demonstrating any movement in the same field. As seen in Figure 6A, the fraction of cells that are motile following transfection with either GFP alone or GFP-hVICKZ1 is very similar to the fraction of neighboring cells that are motile and do not express the transfected plasmids; thus, both of these values are close to 1 . Transfection with GFPhVICKZ1 $\Delta 4$, however, strikingly reduces the normalized fraction of motile cells by approximately threefold. In addition, the distance traversed by cells transfected with the deletion construct, be it the total or net translational distance, is reduced seven- or 10-fold, respectively, relative to nontransfected cells; only a mild reduction in distance traveled is caused by the expression of full-length hVICKZ1 (Fig. 6B). These results show that the hVICKZ1 deletion construct strongly inhibits cell migration in cultured cells. Given the specific nature of the hVICKZ1 $\Delta 4$ inhibition (Fig. $5 \mathrm{~A}$ ), these results imply that the RNA binding activity of hVICKZ proteins is required for motility in these cells.

\section{DISCUSSION}

The identification of a domain in xVICKZ3 responsible for high-affinity binding to specific RNA targets enabled us to generate a deletion construct defective in RNA binding. This construct demonstrates severely reduced VLE and TGF $\beta$ RNA binding, both alone and when complexed with full-length $x V I C K Z 3$. Because the dissociation constant of xVICKZ3$\mathrm{xVICKZ} 3 \Delta 4$ heteromeres is similar to that of full-length xVICKZ3-xVICKZ3 homomeres, $\mathrm{xVICKZ} 3 \Delta 4$ is capable of functioning as a dominant-negative construct when injected into Xenopus embryos; in fact, injection of this construct phenocopies the inhibited cell migration observed when xVICKZ3 protein levels are reduced via antisense morpholino oligonucleotide. Using three different parameters, the corresponding human construct also inhibits cell motility in bladder carcinoma cells induced to move. Thus, we conclude that VICKZ-mediated cell movement requires the protein's RNA binding activity.

Previous structure-function studies made use of VICKZ deletion mutants and constructs containing various subsets of domains to assay for RNA binding. Although there was general agreement that the $\mathrm{N}$-terminal RRM domains of the protein are not required for specific RNA binding, there was less consensus regarding the involvement of specific KH domains (particularly 3 and 4 ) in RNA binding (Git and Standart 2002; Nielsen et al. 2002; Farina et al. 2003; Nielsen et al. 2004). The differences reported in those studies could have been the result of the use of different VICKZ paralogs and RNA targets. Alternatively, how a deletion construct or isolated domain functions may not accurately reflect the role of the region in the context of the whole protein. Here, we first allowed intact, full-length $\mathrm{xVICKZ3}$ to bind its target RNA and then determined to which region in the protein the RNA was bound. This approach has unequivocally identified $\mathrm{KH} 4$ as a domain that binds VLE RNA. Deletion of this region also strongly inhibits RNA binding to another RNA target, TGF $\beta$. The fact that VICKZ $\Delta 4$ prevents UV-cross-linking of full-length VICKZ, but not of other unrelated proteins, argues strongly for the efficacy and specificity of the inhibition. It is important to note that the impairment of UV-cross-linking to a radioactive RNA probe does not necessarily imply that all RNA binding by the protein has been affected. Nevertheless, the strong reduction in UV-cross-linking, observed in the presence of the dominant-negative construct, leads to a pronounced effect on cell migration. These results thus argue that an unimpaired RNA binding activity is required for VICKZ proteins to help mediate cell movement.

VICKZ proteins have been shown to associate with a number of RNAs implicated in cell motility and invasion. In addition to $\beta$-actin mRNA, other such targets include cofilin, an actin depolymerization/severing protein
A

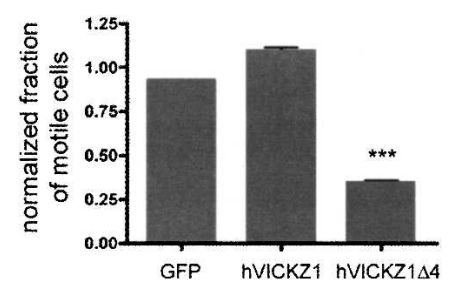

B

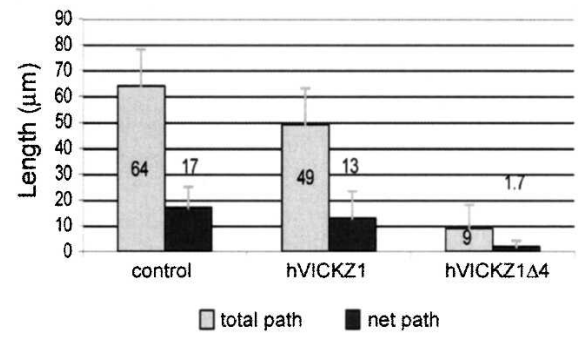

FIGURE 6. hVICKZ1 14 inhibits cell migration of TSU-Pr1 cells. TSU-Pr1 cells were transfected with GFP, GFP-hVICKZ1, or GFP-hVICKZ1 44 under conditions in which only a fraction of the cells expresses the GFP marker. As described in Materials and Methods, cell movement was induced by the isotopic addition of EGF, following serum starvation, and frames were captured every three minutes over the course of $3 \mathrm{~h}$. (A) In each transfection, the fraction of transfected (fluorescent) cells that were motile in a given field was calculated (as described in Materials and Methods) and normalized to the fraction of nontransfected (nonfluorescent) cells in the same field that were motile. For the GFP, GFP-hVICKZ1, and GFP-hVICKZ1 $\Delta 4$ transfections, the results represent data from 22, 50, and 85 cells, respectively, from one, three, and six trials. An average of 25 nontransfected cells were analyzed for each field. Bars indicate standard error of mean. The asterisks indicate that the results with GFP-hVICKZ1 $\Delta 4$ were significantly different $(P<0.001)$ from those obtained with either GFP or GFP-hVICKZ1. (B) Using the DIAS software (see Materials and Methods), the total and net path length traversed by cells transfected with either GFP-hVICKZ1 or GFPhVICKZ1 14 were calculated and compared to the total and net path length traversed by nontransfected cells in the same field. 
associated with lamellipodia formation, cell migration, and invasion (Ghosh et al. 2004; Hotulainen et al. 2005; Piper et al. 2006; Wang et al. 2006), and CD44, a hyaluronan receptor required for invadopodia formation (Vikesaa et al. 2006). By inhibiting RNA binding of the endogenous VICKZ proteins, the dominant-negative construct VICKZ $\Delta 4$ can affect the stability, translation, and/or intracellular localization of these and other target RNAs, thus generating the phenotypes described here, both in embryos and in cultured cells. The specific target RNAs mediating the dominant-negative-induced inhibition of cell migration remain to be elucidated.

The ability of the KH4 deletion to function in a dominant-negative fashion appears to be the result of its ability to associate with full-length VICKZ. This association does not require RNA (data not shown; Fig. 3). These results are consistent with experiments described previously, which demonstrated the ability of xVICKZ3 to selfassociate in the absence of RNA (Git and Standart 2002). Although Nielsen and colleagues concur that self-association can occur without RNA, they have suggested a sequential dimerization model for VICKZ RNP formation (Nielsen et al. 2004). Using a gel shift assay with relatively short RNA probes as targets, they find that RNA binding proceeds first through a monomer VICKZ binding an RNA target, forming an unstable complex that is subsequently stabilized by the binding of a second VICKZ molecule. Based on the protein-protein interaction data presented here (Fig. 3), we conclude that, in the presence of excess VICKZ $\Delta 4$ construct, wild-type VICKZ and VICKZ $\Delta 4$ are likely to associate with each other. We propose that, in both Xenopus embryos and the bladder carcinoma cells, the kinetics of this association will be favored over RNAmonomer VICKZ binding, particularly when the RNA substrate is a full-length RNA (as opposed to the shorter RNA targets used in the Nielsen study). Once the heteromeric construct is formed, this appears to inhibit RNA binding, perhaps by preventing the normal, sequential dimerization/stabilization of the VICKZ-RNA complex. In this regard, we cannot rule out the possibility that the direct effect of the $\mathrm{KH} 4$ deletion may be on the association of full-length VICKZ proteins with requisite protein complexes. Given the fact, however, that the KH4 domain was identified by the mass spectrometry analysis as a domain that binds target RNA, and that, on its own, is capable of binding RNA (F. Oberman and J.K. Yisraeli, unpubl. observations), we favor the model that the formation of a heteromeric complex directly impairs RNA binding.

Git and Standart have shown that the self-association domain of xVICKZ3 can be mapped to its $\mathrm{KH} 3$ and 4 regions (Git and Standart 2002). Our data from both Biacore (Fig. 3; data not shown) and IP (Fig. 5B) experiments indicate that most of $\mathrm{KH} 4$ is not required for selfassociation, and therefore $\mathrm{xVICKZ} 3 \Delta 4$ functions well in dominant-negative inhibition of RNA binding. Deletion of most of $\mathrm{KH} 3$, however, despite generating a molecule that is also defective in VLE RNA binding, does not yield a construct that functions in a dominant-negative fashion. One explanation of this finding is that the deletion in $\mathrm{xVICKZ} 3 \Delta 3$ results in a protein unable to associate either with itself or with full-length $x V I C K Z 3$, thus rendering it incapable of both binding VLE RNA and acting in a dominant-negative fashion. It is not clear at this point whether the last $\alpha$-helix in KH4, which is the only $\alpha$-helix in the four $\mathrm{KH}$ domains that may possess some coiled-coil attributes, is necessary for self-association, although this model would predict that it is not sufficient. Alternatively, $\mathrm{xVICKZ} 3 \Delta 3$ may associate with the full-length $\mathrm{xVICKZ3}$ but nevertheless not prevent its ability to bind RNA, perhaps due to the presence of a normal $\mathrm{KH} 3$ domain in the full-length xVICKZ3 in the heteromere. Regardless of the model, however, the inability of this construct to induce the same phenotype as the $\mathrm{xVICKZ} 3 \Delta 4$ construct, despite their close similarity and presumed retention of various protein interaction domains, strengthens the argument that xVICKZ3 helps mediate cell migration through its ability to bind RNA.

A previous structure-function study of chick VICKZ1 identified two other constructs, $\mathrm{KH} 1-4$ and $\mathrm{KH} 3-4$, as having dominant-negative effects when transfected into chick embryo fibroblasts (Farina et al. 2003). In these cases, the researchers found that both constructs were able to bind $\beta$-actin RNA and form granules. These localizationdefective VICKZ1 constructs thus appear to be competing with wild-type VICKZ1 for the binding of RNA targets. Given that wild-type VICKZ1 in these cells continues to function normally, it is perhaps not surprising that cell migration was only modestly inhibited by these constructs (15\%-20\%). In contrast, the VICKZ 44 constructs described in this paper function in a completely different manner, by inhibiting directly the wild-type VICKZ. The strong levels of inhibition shown here, in both Xenopus embryos and bladder carcinoma cells, suggest that this form of a construct is likely to be a much better candidate for inhibiting endogenous VICKZ activities in a wide range of cell types. This strategy for creating a dominant-negative construct may prove to be useful for inhibiting many RNA binding proteins that demonstrate a cooperative mechanism for generating RNP complexes.

Recently, VICKZ proteins have been reported to help mediate cell adhesion, cell spreading, and invadopodia formation in HeLa cells (Vikesaa et al. 2006). In addition, they appear to help stabilize CD44 RNA that encodes a hyaluronan receptor positively correlated with invadopodia formation and the invasive capacity of cancer cells (Bourguignon et al. 1998; Jothy 2003). Furthermore, signal transduction can lead to spatially restricted phosphorylation of VICKZ that permits localized translation of specific transcripts at the leading edge of cells (Huttelmaier et al. 2005). VICKZ proteins are overexpressed in a 
wide variety of cancers (for review, see Yisraeli 2005), including metastatic colorectal carcinomas (G. Vainer, E. Vainer-Mossel, A. Pikarsky, S. Shenoy, R.H. Singer, E. Pikarsky, and J.K. Yisraeli, in prep.). The data presented here fit nicely with these observations, suggesting that VICKZ proteins may play an important role in facilitating cell migration and metastasis through their interactions with specific RNAs. Expression of the VICKZ $\Delta 4$ construct in metastasizing cells as well as the identification of additional VICKZ RNA targets should greatly enhance our understanding of how this family of RNA binding proteins functions in cell motility.

\section{MATERIALS AND METHODS}

\section{Plasmids and cloning}

VICKZ constructs were cloned into the pET21d plasmid (Novagen) for the synthesis of $6 \times$ His-tag epitope containing expression vectors. The open reading frame of $\mathrm{xVICKZ3} \mathrm{(accession} \mathrm{number}$ AF064634) (Havin et al. 1998) was inserted between the Ncol and XhoI sites of pET21d, as described (Git and Standart 2002). $\mathrm{xVICKZ3 \Delta 4-pET21d} \mathrm{was} \mathrm{generated} \mathrm{using} \mathrm{PCR} \mathrm{to} \mathrm{construct} \mathrm{a}$ deletion of the entire $\mathrm{KH} 4$ domain minus the last $\alpha$-helix in order to create a recombinant protein missing all amino acids between His504 and Gly554, inclusive. Similarly, xVICKZ3 $33-$ pET21d was generated using PCR to construct a deletion of the KH3 domain minus the last $\alpha$-helix, in order to create a recombinant protein missing all amino acids from Glu419 to Thr470. Plasmids containing the open reading frames of both hVICKZ 1 (accession number NM006546) and hVICKZ 2 (accession number NM053122) were gifts from Jan Christiansen (Nielsen et al. 1999). PCR reactions were performed on the full-length plasmids to generate the hVICKZ1 $\Delta 4$ and hVICKZ2 $\Delta 4$ constructs, which would express recombinant proteins with deletions between amino acids His491 and Ile540 and His511 to Ile560 for hVICKZ1 and hVICKZ2, respectively. Both the hVICKZ1 and hVICKZ1 44 constructs were inserted between the NcoI and XhoI sites of pET21d. Expression and purification of the recombinant proteins in Escherichia coli BL21 cells were as described (Havin et al. 1998; Nielsen et al. 2004).

To prepare the $x$ VICKZ $\Delta 4-G F P-p E T 21 d$ construct for injections into embryos, a GFP fragment was inserted between the Xhol and Smal sites of the xVICKZ3-pET21d construct and the KH4 region was deleted by PCR. To prepare the $\mathrm{xVICKZ3} \Delta 4$ GFP-pCS2+ construct for injections into embryos, the $\mathrm{xVICKZ3 \Delta 4-GFP}$ fragment was inserted between the BamHI and EcoRI sites of the pCS2+ plasmid (gift of Dr. Abraham Fainsod, Hebrew University, Hadassah Medical School).

For expression in cultured cells, the VICKZ constructs were cloned into pEGFP plasmid vectors (Clonetech, BD Biosciences). $\mathrm{xVICKZ3}$ and $\mathrm{xVICK} 3 \Delta 4$ were cloned into pEGFP-C3, by first introducing the PCR-amplified products into the EcoRI site of the pGEM-T easy cloning vector (Promega) and then transferring them into the EcoRI site of the pEGFP-C3 vector. Similarly, the hVICKZ1 and hVICKZ2, as well as the deletion mutations, the hVICKZ1 $\Delta 4$ and hVICKZ2 $\Delta 4$, were cloned into pEGFP-C1 at the EcoRI site. The deletion and/or orientation of each construct were confirmed by sequencing.

\section{RNA binding assays}

For the UV-cross-linking assays, the VLE, TGF $\beta$ (Schwartz et al. 1992), and IGF-2 leader 3 (Nielsen et al. 1995) RNAs were generated by in vitro transcription of linearized DNA templates using the Riboprobe in vitro System (Promega) in the presence of $80 \mu \mathrm{Ci}$ per reaction ${ }^{32} \mathrm{P}$-UTP (Amersham, $800 \mathrm{Ci} / \mathrm{mmol}$ ) to a specific activity of $0.5 \times 10^{6} \mathrm{cpm} / \mathrm{ng}$. The cross-linking assays were performed as described (Schwartz et al. 1992; Havin et al. 1998; Runge et al. 2000) by binding the ${ }^{32} \mathrm{P}$-labeled probe $(0.8 \mathrm{ng}$, $0.5 \times 10^{6} \mathrm{cpm} /$ reaction) to either recombinant proteins (see plasmid cloning), cell extracts (see tissue culture section), or oocyte and embryo extracts (see Xenopus section).

For the mobility shift assay, $5000 \mathrm{cpm}$ of $\left[\gamma_{-}{ }^{32} \mathrm{P}\right]$-ATP labeled VLE RNA probe $(0.08 \mathrm{ng})$ was incubated with increasing amounts of recombinant xVICKZ3 in RNA binding buffer (Schwartz et al. 1992) in the presence of $5 \mu \mathrm{g}$ tRNA and 8 units RNasin (Promega), in a final volume of $20 \mu \mathrm{L}$ (Mowry 1996). The reactions were incubated for $30 \mathrm{~min}$ at room temperature, run on a $4 \%$ nondenaturing acrylamide gel at $4^{\circ} \mathrm{C}$ and autoradiographed. Unlabeled competitor RNAs, VLE and Vg1 $\Delta \mathrm{HB}$ (a Vg1 RNA construct that does not bind xVICKZ3 [Schwartz et al. 1992]), were synthesized using the Cap Scribe RNA kit (Roche).

\section{Identification of VLE RNA binding site in XVICKZ3}

Purified xVICKZ3 was UV-cross-linked to VLE RNA and digested with RNase A (1 mg/mL) as described (Schwartz et al. 1992). The mass of the cross-linked protein was measured by mass spectrometry, using an electrospray quadrapole-iontrap mass spectrometer and matrix-assisted laser-desorption-ionization time-of-flight (MALDI-TOF) and compared to UV-cross-linked protein without the VLE RNA, in order to calculate the amount of RNA residues found. Following trypsin digestion, the peptides were subjected to reverse phase HPLC separation. The separated peaks were detected by UV and then the sample was split on-line by electrospray mass spectrometry, and off-line by MALDI-TOF. By comparing mock- and VLE-cross-linked protein, a peptide was identified that was specifically bound to the VLE. A 15 amino acid sequence of the bound peptide was determined based on its mass and confirmed by Edmond degradation that corresponded to amino acids 539-553 of xVICKZ3.

\section{Equilibrium binding analysis of protein-protein interactions}

A standard carboxymethylated dextran matrix sensor chip, CM5 (research grade, Biacore \#BR-1000-12) was used for all the Biacore experiments. The ligand was bound by amine coupling (using EDC-N-ethyl- $\mathrm{N}^{\prime}$-[dimethylaminopropyl]-corbodinmide+ NHS-N-hydroxy-succicinimide) and blocked with ethanol amine, according to Biacore instructions. The protein was then immobilized with $10 \mathrm{mM}$ acetate $\mathrm{pH}$ 5.0. The level of ligand binding achieved was $600 \mathrm{RU}$. Increasing concentrations of analyte (0$1000 \mathrm{nM}$ ) were injected at a flow rate of $30 \mu \mathrm{L} / \mathrm{min}$. The running buffer contained $10 \mathrm{mM}$ HEPES pH 7.4, $200 \mathrm{mM} \mathrm{NaCl}, 3.4 \mathrm{mM}$ EDTA, and $0.005 \%$ Tween 20. Regeneration was done by injecting $10 \mu \mathrm{L} 100 \mathrm{mM} \mathrm{NaOH}$. Analysis of equilibrium binding constants was performed using Biacore evaluation software 4.0.1 using 1:1 Langmuir model. 


\section{Xenopus oocytes, embryos, and injections}

S10 protein extracts were prepared from Xenopus embryos and oocytes by homogenization in TGKED buffer and spinning at $10,000 \mathrm{~g}$ to clear the extracts, as described (Elisha et al. 1995). For fertilizations eggs were stripped, fertilized, and injected as previously described (Epstein et al. 1997). Embryos were maintained in $0.1 \times$ Modified Barth's Solution-HEPES (MBSH) and, at the two-cell stage, they were transferred to $1 \times \mathrm{MBSH}$ for injection. Morpholino oligonucleotides, as previously described (Yaniv et al. 2003), were injected into both blastomeres at a concentration of 0.8-1.2 pmol/blastomere. For the dominant-negative experiments GFP-xVICKZ3 $\Delta 4$ RNA was synthesized from either the xVICKZ3 $\Delta 4-$ GFP-pET21d plasmid or the xVICKZ3 $\Delta 4-$ GFPpCS2+ plasmid using the Cap Scribe RNA kit (Roche). The $x V I C K Z 3 \Delta 3$ capped RNA was similarly synthesized from the $\mathrm{xVICKZ3} \Delta 3$-pET21d plasmid. Between 0.8 and $2.0 \mathrm{ng}$ of capped RNA was injected into each blastomere of a two-cell stage embryo. Both injected and uninjected embryos were staged according to Nieuwkoop and Faber (1967), and not on the basis of elapsed time from fertilization. The embryos were scored according to eye, fin, and pigment phenotype to determine percentage of mutants.

\section{Tissue culture and transfections}

Human embryonic kidney cells (HEK293) were maintained in Dulbecco's modified Eagle's medium (Sigma) containing 10\% fetal calf serum (Biological Industries, Beit HaEmek) and $10 \mu \mathrm{g} / \mathrm{mL}$ ciprofloxacin (Bayer). TSU-Pr1 cells, a bladder transitional cell carcinoma cell line (van Bokhoven et al. 2001), were kindly provided by Dr. Shoshana Ravid (Hebrew University, Hadassah Medical School). Cells were maintained in RPMI-1640 (Sigma) supplemented with $10 \%$ fetal calf serum, $100 \mathrm{U} / \mathrm{mL}$ penicillin, 100 $\mu \mathrm{g} / \mathrm{mL}$ streptomycin, and $10 \mu \mathrm{g} / \mathrm{mL}$ ciprofloxacin. All cells were grown in a humidified atmosphere of $5 \% \mathrm{CO}_{2}$ and $95 \%$ air, at $37^{\circ} \mathrm{C}$. Transient transfections were performed with Lipofectamine 2000 (Invitrogen) according to the manufacturer's instructions.

To prepare HEK293 cell extracts for UV-cross-linking and immunoprecipitation for Western blot analysis, cells were lysed in $20 \mathrm{mM}$ Tris, pH 7.0, $150 \mathrm{mM} \mathrm{NaCl}, 5 \mathrm{mM}$ EDTA, 1\% Triton $\mathrm{X}-100$, and $1 \times$ Protease Cocktail (Sigma). They were held on ice for $30 \mathrm{~min}$ with intermittent vortexing, spun at 14,000 rpm for 30 min, and frozen in aliquots at $-70^{\circ} \mathrm{C}$. The protein concentrations were estimated using the Bio-Rad protein assay kit.

\section{Analysis of cell movement}

To assay the effects of VICKZ constructs on cell migration, TSUPr1 cells were transiently transfected with the appropriate plasmid. The amount of plasmid used for transfection was calibrated to give transfection efficiency of $\sim 30 \%$. This insured that nontransfected cells would also be present in every field, allowing for an internal control of cell migration. The following day, cells were sparsely replated onto $33 \mathrm{~mm}$ Petri dishes, and cell movement was assayed on the second day following transfection. Cells were first serumstarved for $3 \mathrm{~h}$ in RPMI containing $25 \mathrm{mM}$ HEPES (conditions that were found to cause $87 \%$ of the cells to become sessile), and then $7 \mathrm{ng} / \mathrm{mL}$ of EGF (Sigma E9644) was added to induce movement. Images were acquired, at $100 \times$ magnification, every 3 min over a 3 -h period using a CCD air-cooled camera attached to a standard inverted fluorescent microscope equipped with a device that maintained a temperature of $37^{\circ} \mathrm{C}$ by injection of humidified, preheated air. The pictures were subsequently processed using Image Pro, version 4 software (sample movies of transiently transfected TSU-Pr1 cells are available upon request).

Three separate parameters of cell movement were obtained from the time lapse stacks. To determine the normalized fraction of motile cells in a transfected plate, all of the fluorescent cells in a given field were scored as either motile or sessile. A cell was considered motile if, at any point during the $3 \mathrm{~h}$, its nucleus clearly demonstrated translational movement. If a cell only changed its shape around the nucleus, it was scored as sessile. The fraction of transfected (fluorescent) cells that were motile was then normalized to the fraction of nontransfected (nonfluorescent) cells that were motile (in the same field). The results were analyzed by nonparametric one-way ANOVA (Kruskal-Wallis test) with post-test pairwise comparisons, using GraphPad Prism 4 (GraphPad Software, Inc.).

In order to calculate the actual distances moved by the induced cells, the stacks were first prepared for tracing using the public software "prepare-for-tracing02" (available for download from the site of the Analytical Image Facilities [AIF] of the Albert Einstein College of Medicine [www.aecom.yu.edu/aif/]). Individual cells were then traced using the "ImageJ" program (NIH). The total or net translational distance for each cell was obtained using the "DIAS" software, version 3.4.1 (Dynamic Image Analysis System from Soll Technologies, Inc.). Nontransfected cells present in the same field as the transfected cells were used as controls.

\section{Western blot analysis and immunoprecipitation}

For Western blot analysis of embryo extracts, one embryo equivalent was resolved on $8 \%$ PAGE gels, transferred to a Protran membrane and probed with a 1:20,000 dilution of an xVICKZ3 rabbit polyclonal antibody (Natkunam et al. 2007), as previously described (Yaniv et al. 2003). HEK293 cell extracts were similarly analyzed by Western blots. Immunoprecipitations were performed by incubating $2 \mu \mathrm{g}$ anti-GFP, IgG antibody (Molecular Probes) with $30 \mu \mathrm{L}$ Protein A-Sepharose beads (Amersham) in immunoprecipitation buffer $(150 \mathrm{mM} \mathrm{NaCl}, 10 \mathrm{mM}$ Tris, $\mathrm{pH}$ 7.0, $1 \mathrm{mM}$ EDTA, $1 \mathrm{mM}$ EGTA, $0.5 \% \mathrm{NP}-40$, and $1 \times$ Protease Inhibitor Cocktail) overnight. After washing the beads three times in the above buffer, equivalent amounts of cell extracts were added and incubated with the beads for a minimum of $4 \mathrm{~h}$. The complexes were again rinsed three times in the buffer, resuspended in Laemmli dye, and run on a 10\% PAGE-SDS gel for Western blotting with the xVICKZ3 antibody (1:20,000 dilution).

\section{ACKNOWLEDGMENTS}

We thank Jan Christiansen for providing the hVICKZ1, hVICKZ2, and Igf2-leader 3 plasmids, Gilad Vainer for the GFP-hVICKZ1 and GFP-hVICKZ2 constructs and help with the cell movement assay, Michal Shoshkes for help with the analysis of the injected embryos, Arie Admon for the mass spectrometry analysis, and Hagit Zer and Susana Shohat for the Biacore analysis. We would like to express our appreciation to Rob Singer for allowing us to perform cell movement analyses in his lab, and to Kyle Lapidus for his help with the DIAS analysis. We would also like to thank Zeev Paroush, as well as the members of the Yisraeli laboratory, for 
constructive comments on the manuscript. Different aspects of this work were supported by grants from the Israel Science Foundation, the US-Israel Binational Foundation, Israel Cancer Research Fund, and the Association of International Cancer Research.

Received March 14, 2007; accepted June 8, 2007.

\section{REFERENCES}

Allison, R., Czaplinski, K., Git, A., Adegbenro, E., Stennard, F., Houliston, E., and Standart, N. 2004. Two distinct Staufen isoforms in Xenopus are vegetally localized during oogenesis. RNA. 10: 1751-1763.

Betley, J.N., Heinrich, B., Vernos, I., Sardet, C., Prodon, F., and Deshler, J.O. 2004. Kinesin II mediates Vg1 mRNA transport in Xenopus oocytes. Curr. Biol. 14: 219-224.

Bourguignon, L.Y., Gunja-Smith, Z., Iida, N., Zhu, H.B., Young, L.J., Muller, W.J., and Cardiff, R.D. 1998. CD44v(3,8-10) is involved in cytoskeleton-mediated tumor cell migration and matrix metalloproteinase (MMP-9) association in metastatic breast cancer cells. J. Cell. Physiol. 176: 206-215.

Chen, T., Damaj, B.B., Herrera, C., Lasko, P., and Richard, S. 1997. Self-association of the single-KH-domain family members Sam68, GRP33, GLD-1, and Qk1: Role of the KH domain. Mol. Cell. Biol. 17: $5707-5718$.

Condeelis, J. and Singer, R.H. 2005. How and why does beta-actin mRNA target? Biol. Cell. 97: 97-110.

Cote, C.A., Gautreau, D., Denegre, J.M., Kress, T.L., Terry, N.A., and Mowry, K.L. 1999. A Xenopus protein related to hnRNP I has a role in cytoplasmic RNA localization. Mol. Cell. 4: 431-437.

Czaplinski, K. and Mattaj, I.W. 2006. 40LoVe interacts with Vg1RBP/ Vera and hnRNP I in binding the Vgl-localization element. RNA. 12: 213-222.

Czaplinski, K., Kocher, T., Schelder, M., Segref, A., Wilm, M., and Mattaj, I.W. 2005. Identification of 40LoVe, a Xenopus hnRNP D family protein involved in localizing a TGF-beta-related mRNA during oogenesis. Dev. Cell. 8: 505-515.

Deshler, J.O., Highett, M.I., Abramson, T., and Schnapp, B.J. 1998. A highly conserved RNA-binding protein for cytoplasmic mRNA localization in vertebrates. Curr. Biol. 8: 489-496.

Elisha, Z., Havin, L., Ringel, I., and Yisraeli, J.K. 1995. Vg1 RNA binding protein mediates the association of Vgl RNA with microtubules in Xenopus oocytes. EMBO J. 14: 5109-5114.

Eom, T., Antar, L.N., Singer, R.H., and Bassell, G.J. 2003. Localization of a beta-actin messenger zipcode-binding protein modulates the density of filopodial synapses. J. Neurosci. 23: 10433-10444.

Epstein, M., Pillemer, G., Yelin, R., Yisraeli, J.K., and Fainsod, A. 1997. Patterning of the embryo along the anterior-posterior axis: The role of the caudal genes. Development. 124: 3805-3814.

Farina, K.L., Huttelmaier, S., Musunuru, K., Darnell, R., and Singer, R.H. 2003. Two ZBP1 KH domains facilitate $\beta$-actin mRNA localization, granule formation, and cytoskeletal attachment. J. Cell Biol. 160: 77-87.

Ghosh, M., Song, X., Mouneimne, G., Sidani, M., Lawrence, D.S., and Condeelis, J.S. 2004. Cofilin promotes actin polymerization and defines the direction of cell motility. Science. 304: 743-746.

Gibson, T.J., Thompson, J.D., and Abagyan, R.A. 1993. Proposed structure for the DNA-binding domain of the helix-loop-helix family of eukaryotic gene regulatory proteins. Protein Eng. 6: $41-50$.

Git, A. and Standart, N. 2002. The KH domains of Xenopus Vg1RBP mediate RNA binding and self-association. RNA. 8: 1319-1333.

Havin, L., Git, A., Elisha, Z., Oberman, F., Yaniv, K., Schwartz, S.P., Standart, N., and Yisraeli, J.K. 1998. RNA-binding protein conserved in both microtubule- and microfilament-based RNA localization. Genes \& Dev. 12: 1593-1598.
Hotulainen, P., Paunola, E., Vartiainen, M.K., and Lappalainen, P. 2005. Actin-depolymerizing factor and cofilin-1 play overlapping roles in promoting rapid F-actin depolymerization in mammalian nonmuscle cells. Mol. Biol. Cell. 16: 649-664.

Huttelmaier, S., Zenklusen, D., Lederer, M., Dictenberg, J., Lorenz, M., Meng, X., Bassell, G.J., Condeelis, J., and Singer, R.H. 2005. Spatial regulation of $\beta$-actin translation by Src-dependent phosphorylation of ZBP1. Nature. 438: 512-515.

Jothy, S. 2003. CD44 and its partners in metastasis. Clin. Exp. Metastasis. 20: 195-201.

Kress, T.L., Yoon, Y.J., and Mowry, K.L. 2004. Nuclear RNP complex assembly initiates cytoplasmic RNA localization. J. Cell Biol. 165: 203-211.

Kroll, T.T., Zhao, W.M., Jiang, C., and Huber, P.W. 2002. A homolog of FBP2/KSRP binds to localized mRNAs in Xenopus oocytes. Development. 129: 5609-5619.

Leung, K.M., van Horck, F.P., Lin, A.C., Allison, R., Standart, N., and Holt, C.E. 2006. Asymmetrical $\beta$-actin mRNA translation in growth cones mediates attractive turning to netrin-1. Nat. Neurosci. 9: $1247-1256$.

Lewis, R.A., Kress, T.L., Cote, C.A., Gautreau, D., Rokop, M.E., and Mowry, K.L. 2004. Conserved and clustered RNA recognition sequences are a critical feature of signals directing RNA localization in Xenopus oocytes. Mech. Dev. 121: 101-109.

Lupas, A., Van Dyke, M., and Stock, J. 1991. Predicting coiled coils from protein sequences. Science. 252: 1162-1164.

Moraes, K.C., Quaresma, A.J., Maehnss, K., and Kobarg, J. 2003. Identification and characterization of proteins that selectively interact with isoforms of the mRNA binding protein AUF1 (hnRNP D). Biol. Chem. 384: 25-37.

Mowry, K.L. 1996. Complex formation between stage-specific oocyte factors and a Xenopus mRNA localization element. Proc. Natl. Acad. Sci. 93: 14608-14613.

Musco, G., Stier, G., Joseph, C., Castiglione Morelli, M.A., Nilges, M., Gibson, T.J., and Pastore, A. 1996. Three-dimensional structure and stability of the $\mathrm{KH}$ domain: Molecular insights into the fragile X syndrome. Cell. 85: 237-245.

Natkunam, Y., Vainer, G., Chen, J., Zhao, S., Marinelli, R.J., Hammer, A.S., Hamilton-Dutoit, S., Pikarsky, E., Amir, G., Levy, R., et al. 2007. Expression of the RNA-binding protein VICKZ in normal hematopoietic tissues and neoplasms. Haematologica. 92: 176-183.

Nielsen, F.C., Ostergaard, L., Nielsen, J., and Christiansen, J. 1995. Growth-dependent translation of IGF-II mRNA by a rapamycinsensitive pathway. Nature. 377: 358-362.

Nielsen, J., Christiansen, J., Lykke-Andersen, J., Johnsen, A.H., Wewer, U.M., and Nielsen, F.C. 1999. A family of insulin-like growth factor II mRNA-binding proteins represses translation in late development. Mol. Cell. Biol. 19: 1262-1270.

Nielsen, F.C., Nielsen, J., Kristensen, M.A., Koch, G., and Christiansen, J. 2002. Cytoplasmic trafficking of IGF-II mRNA-binding protein by conserved KH domains. J. Cell Sci. 115: 2087-2097.

Nielsen, J., Kristensen, M.A., Willemoes, M., Nielsen, F.C., and Christiansen, J. 2004. Sequential dimerization of human zipcode-binding protein IMP1 on RNA: A cooperative mechanism providing RNP stability. Nucleic Acids Res. 32: 4368-4376.

Nieuwkoop, P.D. and Faber, J. 1967. Normal table of Xenopus laevis (Daudin). In A systematical and chronological survey of the development from the fertilized egg till the end of metamorphosis. North-Holland, Amsterdam.

Oleynikov, Y. and Singer, R.H. 2003. Real-time visualization of ZBP1 association with beta-actin mRNA during transcription and localization. Curr. Biol. 13: 199-207.

Patel, G.P., Ma, S., and Bag, J. 2005. The autoregulatory translational control element of poly(A)-binding protein mRNA forms a heteromeric ribonucleoprotein complex. Nucleic Acids Res. 33: 7074-7089.

Piper, M., Anderson, R., Dwivedy, A., Weinl, C., van Horck, F., Leung, K.M., Cogill, E., and Holt, C. 2006. Signaling mechanisms 
underlying Slit2-induced collapse of Xenopus retinal growth cones. Neuron. 49: 215-228.

Ross, A.F., Oleynikov, Y., Kislauskis, E.H., Taneja, K.L., and Singer, R.H. 1997. Characterization of a beta-actin mRNA zipcode-binding protein. Mol. Cell. Biol. 17: 2158-2165.

Runge, S., Nielsen, F.C., Nielsen, J., Lykke-Andersen, J., Wewer, U.M., and Christiansen, J. 2000. H19 RNA binds four molecules of insulin-like growth factor II mRNA-binding protein. J. Biol. Chem. 275: 29562-29569.

Schwartz, S.P., Aisenthal, L., Elisha, Z., Oberman, F., and Yisraeli, J.K. 1992. A $69-\mathrm{kDa}$ RNA binding protein from Xenopus oocytes recognizes a common motif in two vegetally localized maternal mRNAs. Proc. Natl. Acad. Sci. 89: 11895-11899.

Shestakova, E.A., Singer, R.H., and Condeelis, J. 2001. The physiological significance of beta-actin mRNA localization in determining cell polarity and directional motility. Proc. Natl. Acad. Sci. 98: 7045-7050.

van Bokhoven, A., Varella-Garcia, M., Korch, C., and Miller, G.J. 2001. TSU-Pr1 and JCA-1 cells are derivatives of T24 bladder carcinoma cells and are not of prostatic origin. Cancer Res. 61: 6340-6344.

Vikesaa, J., Hansen, T.V., Jonson, L., Borup, R., Wewer, U.M., Christiansen, J., and Nielsen, F.C. 2006. RNA-binding IMPs promote cell adhesion and invadopodia formation. EMBO J. 25: $1456-1468$.

Wang, W., Goswami, S., Lapidus, K., Wells, A.L., Wyckoff, J.B., Sahai, E., Singer, R.H., Segall, J.E., and Condeelis, J.S. 2004. Identification and testing of a gene expression signature of invasive carcinoma cells within primary mammary tumors. Cancer Res. 64: 8585-8594.

Wang, W., Mouneimne, G., Sidani, M., Wyckoff, J., Chen, X., Makris, A., Goswami, S., Bresnick, A.R., and Condeelis, J.S.
2006. The activity status of cofilin is directly related to invasion, intravasation, and metastasis of mammary tumors. J. Cell Biol. 173: $395-404$.

Yaniv, K. and Yisraeli, J.K. 2001. Defining cis-acting elements and trans-acting factors in RNA localization. Int. Rev. Cytol. 203: 521-539.

Yaniv, K. and Yisraeli, J.K. 2002. The involvement of a conserved family of RNA binding proteins in embryonic development and carcinogenesis. Gene. 287: 49-54.

Yaniv, K., Fainsod, A., Kalcheim, C., and Yisraeli, J.K. 2003. The RNAbinding protein Vg1 RBP is required for cell migration during early neural development. Development. 130: 5649-5661.

Yao, J., Sasaki, Y., Wen, Z., Bassell, G.J., and Zheng, J.Q. 2006. An essential role for $\beta$-actin mRNA localization and translation in $\mathrm{Ca}^{2+}$-dependent growth cone guidance. Nat. Neurosci. 9: 12651273.

Yisraeli, J.K. 2005. VICKZ proteins: A multi-talented family of regulatory RNA-binding proteins. Biol. Cell. 97: 87-96.

Yisraeli, J.K., Sokol, S., and Melton, D.A. 1990. A two-step model for the localization of a maternal mRNA in Xenopus oocytes: Involvement of microtubules and microfilaments in translocation and anchoring of Vg1 mRNA. Development. 108: 289-298.

Yoon, Y.J. and Mowry, K.L. 2004. Xenopus Staufen is a component of a ribonucleoprotein complex containing Vg1 RNA and kinesin. Development. 131: 3035-3045.

Zhang, J.Y., Chan, E.K., Peng, X.X., and Tan, E.M. 1999. A novel cytoplasmic protein with RNA-binding motifs is an autoantigen in human hepatocellular carcinoma. J. Exp. Med. 189: 1101-1110.

Zhao, W.M., Jiang, C., Kroll, T.T., and Huber, P.W. 2001. A prolinerich protein binds to the localization element of Xenopus Vg1 mRNA and to ligands involved in actin polymerization. EMBO J. 20: $2315-2325$. 

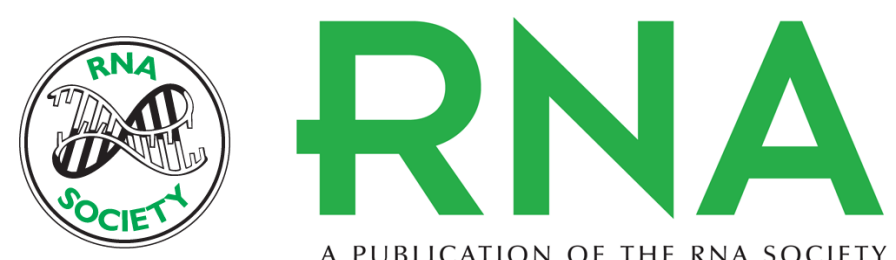

A PUBLICATION OF THE RNA SOCIETY

\section{VICKZ proteins mediate cell migration via their RNA binding activity}

Froma Oberman, Kinneret Rand, Yael Maizels, et al.

RNA 2007 13: 1558-1569 originally published online July 24, 2007

Access the most recent version at doi:10.1261/rna.559507

\section{References This article cites 53 articles, 28 of which can be accessed free at: http://rnajournal.cshlp.org/content/13/9/1558.full.html\#ref-list-1}

\section{License}

Email Alerting Receive free email alerts when new articles cite this article - sign up in the box at the Service top right corner of the article or click here.

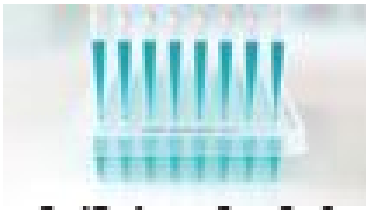

